\title{
An Empirical Investigation of the Relationship between Executive Risk Sharing and Stock Performance in New and Old Economy Firms
}

\author{
Mohamed I. Gomaa \\ Assistant Professor \\ Suffolk University, 8 Asburton Place, Boston, MA 02108, USA \\ Tel: 1-617-305-1973Fax: (617) 994-4260Ｅ-mail: mgomaa@suffolk.edu
}

Received: February 29, 2012

Accepted: April 2, 2012

Published: May 15, 2012

doi:10.5430/afr.v1n1p106

URL: http://dx.doi.org/10.5430/afr.v1n1p106

\begin{abstract}
Compensation contracts used in different firms embody both incentive and risk sharing components. This study builds on the existing literature by empirically investigating the relationship between executive risk sharing and firms' stock performance in new and old economy firms. It tries to answer the fundamental question of whether or not using risk sharing contracts actually motivate executives to increase shareholder value, and whether that effect differs between new and old economy firms. The results indicate that the level of risk sharing does not influence the future market value of firm shares in high-risk sharing and new economy firms. However, it does negatively influence the current and future return to shareholders. The results also indicate that more intensive stock-based contacts positively influence current and future stock performance. This indicates that although stock based compensation includes a level of risk sharing, the level of risk sharing is not what drives stock performance in high-risk sharing and new economy firms. Rather, it is the value of the stock based compensation that drives performance leading to a higher market value per share and higher return to shareholders.
\end{abstract}

Keywords: Executive risk sharing, Stock performance, New economy firms

\section{Introduction}

There is a growing line of research on the relationship between executive compensation and firm performance in publicly owned corporations. Much of that research employs the agency theory to explain incentives in compensation contracts and performance (e.g., Indjejikian, 1999; Bushman \&Indjejikian, 1993; Lambert \&Larcker, 1987). The common proposition underlying this line of research is that in order to motivate executives to spend effort and work for the best interest of the shareholders, compensation contracts should include some form of incentive component (Hayes \& Schaefer, 2000; Indjejikian, 1999; Baber et al., 1999; Sloan, 1993). Such an incentive component should establish a link between executive compensation and the performance of the firm they manage. Shareholders are mainly interested in the value of the firm and the stock return they receive. Executive compensation can be used as an effective instrument for creating value for shareholders by improving their firm's performance (Gong, 2011; El Akremi et al, 2001).

Survey studies show that performance measures and the structure of incentive contracts vary substantially across firms and industries (Indjejikian, 1999). This is even more evident in new economy firms, where stock-based compensation is extensively used compared to old economy firms (Vieito et al., 2008; Murphy, 2003; Ittner et al., 2003; Anderson et al., 2000). Even with the differences in compensation contracts used in different firms, and whether compensation is linked to firm performance measured by accounting information or the performance of the share price in the market, it embodies both the incentive and risk sharing effects (Gomaa, 2003).

Despite the richness of executive compensation literature, most of the research is limited to CEO contracts, and concerned with issues related to the examination of the determinants of compensation contracts, and how to design an optimal contract that aligns CEOs' and shareholders' objectives. Research on compensation risk, risk sharing and the consequences of using different types of incentive contracts on firm performance has also been limited due to the lack of good empirical measures (Abdel-khalik, 1998). His results provide evidence that risk-sharing in compensation contracts has a significant effect on shareholders rate of return. Other studies tried to examine whether or not incentive contracts actually motivate executives (Leonard, 1990; Abowd, 1990). These studies tried to investigate the impact of incentives on stock-market return. Murphy (2003), Ittner et al. (2003) and Anderson et al. (2000) tried to examine the same issue in 
new economy firms. They argue that the extensive use of equity grants by new economy firms has allowed them to improve performance and provide incentives for executives to enhance shareholder value (Ittner, 2003). The results of these studies suggest that there is a relationship between risk-sharing and firm performance, and that such a relationship is significantly different in new economy firms from that of the old economy firms.

This study builds on the existing literature by empirically investigating the relationship between executive risk sharing and firms' stock performance in new and old economy firms. It tries to answer the fundamental question of whether or not using risk sharing contracts actually motivate executives to increase shareholder value, and whether that effect differs between new and old economy firms. This study is motivated by: (1) the lack of conclusive evidence in the existing literature about the effect of risk sharing on firm's stock performance, (2) the lack of evidence on the relationship between incentives given to top executives, other than the CEOs, and firm's stock performance, and (3) the emergence of a new line of research concerned with the new economy firms, and the relationship between the incentive contracts use in these firms and their success.

Consistent with prior research, this study employs the agency framework to establish a theoretical framework for analysis. It contributes to the existing literature by providing additional evidence on the effect of risk sharing on stock performance and investigating that relationship in both new and old economy firms. The study does not limit its investigation, as most of the existing research did, to the relationship between CEO compensation and firm performance. The effect of risk sharing and other incentives in compensation contracts is also examined.

The study results show that the level of risk sharing does not influence the future market value of firm shares in high-risk sharing and new economy firms. However, it does negatively influence the current and future return to shareholders. The results also indicate that more intensive stock-based contacts positively influence current and future stock performance. These results indicate that even though stock based compensation contracts include a level of risk sharing, the level of risk sharing is not what drives stock performance in high-risk sharing and new economy firms. Alternatively, it is the value of the stock based compensation that drives performance leading to a higher market value per share and higher return to shareholders.

The remainder of this paper is organized as follows: Section 2 presents the theoretical background and hypotheses development, followed by the research design in Section 3. The results of the study and the analysis of results will be presented in Section 4. Finally, Section 5 will include concluding remarks.

\section{Theoretical Background}

\subsection{Compensation and Performance}

The relationship between shareholders and top executives in publicly owned corporations is a classic example of the principle-agent relationship described in the agency theory literature. In a typical agency relationship, the principal hires an agent to act on his/her behalf. Actions taken by the agent have crucial effects on the principal's wealth, yet these actions are often unobservable to the principle. To induce desired actions, a compensation contract must be designed to give the agent proper incentives. In general, "agency theory predicts that compensation policy will tie the agent's expected utility to the principal's objectives" (Jensen \& Murphy, 1990, p. 242). They point out that since "the objective of shareholders (in a corporation) is to maximize wealth; agency theory predicts that CEO compensation policies will depend on changes in shareholder wealth" (Jensen \& Murphy, 1990, p, 242). This prediction is based on three postulates: "(1) ... there is a potential divergence of interest between shareholders and the CEO, (2) ...the existence of an information asymmetry which makes it difficult for the shareholders to (observe) the activities of the CEO, (3) ...the $\mathrm{CEO}$, as a rational agent, seeks to maximize his or her utility and at the same time has an aversion of risk" (El Akremi, et al, 2001, p. 6). Due to the high monitoring cost, the shareholders are left with the option to construct contracts based on surrogate measures of performance that align executives and shareholders objectives. The use of surrogates as a basis for contracting between executives and shareholders, however, may result in a reduction in an executive's incentive to exert the proper effort because the surrogates may not capture all of the performance attributes (Holmstrom, 1979). Thus, with imperfect information most agency relationships must deal with the incentive problem.

As outlined in the agency literature, a compensation contract should include two components; a measure of performance, and an incentive structure. Recent research shows that different performance measures and incentive schemes are suggested in the literature and used in practice (e.g., Ittner et al., 2003; Murphy, 2003; Kren 2001; Jensen \& Murphy, 1990). The existence of different performance measures and incentive schemes implies that there is no consensus as to their usefulness. Many researchers have examined the relative usefulness of financial measures of performance in designing executive compensation contracts. They examined different types of accounting-based, stock-based and relative measures of performance. The results, however, are not conclusive. Lambert and Larker (1987) argue that 
accounting measures of performance are less informative than stock-based measures about management performance in high growth firms. Clinch (1991) found similar results in high R\&D firms. Other researchers provide evidence in support of the use of accounting-based measures of performance. Shim et al. (1999) investigated the determinants of executive compensation in financial institutions. They found that executive compensation is positively related to financial measures of performance. Bizjak et al. (1993) and Gaver and Gaver (1993), however, argue that accounting-based measures of performance affect investment decisions and encourage managers to emphasize short-term performance. Jensen and Murphy (1990) point out that although academic research has usually found a positive correlation between financial performance and executive compensation, they also noted that the associations are modest and explain little of the variance in compensation.

Recent studies show that there is a rapid increase in using stock-based measures of performance in recent years (Ittner et al., 2003; Murphy, 2003; Aggarwal\&Samwick (1999); Hall \&Liebman, 1998; Yarmack, 1995). This is consistent with the argument that shareholders can induce optimal decisions by structuring managerial compensation contracts to balance both future and current stock performance (Gong, 2011; Bizjak et al., 1993). The results of Bizjak et al., (1993) suggest that firms with high information asymmetries between managers and shareholders will tend to favor contracts that emphasize equity ownership relative to salary and bonus incentives. Such contracts focus on long-term return rather than short-term stock return alone.

The above review suggests that there is no conclusive evidence as to the efficiency of performance measures used in executive compensation contracts. Both accounting-based and stock-based contracts have shortcomings. Existing literature, however, suggest that stock-based contracts provide better incentives for long-term performance.

\subsection{Risk Sharing in Compensation Contracts}

A typical executive compensation contract includes two components: Salary plus some performance-based reward. The performance-based component usually includes acash bonus tied to some accounting measure of performance, stock options, and/or other long-term incentive plans. While salaries are basically fixed, the variability of the performance-based component reflects the level of risk executives share with the owners. As noted by Abdel-khalik (1998), compensation variability represents only one contractual risk component. Another important element of compensation risk is the executive equity ownership. An executive may acquire ownership of voting shares at present and/or options to acquire equity ownership at future dates.

Many researchers criticize the use of a cash bonus as an incentive component in executive compensation contracts (e.g., Sigler, 2011; Gaver\&Gaver, 1993). They argue that since a cash bonus is linked to current performance, it usually encourages the decisions which are reflected in current year measures. Since current earnings is not a good measure of future period effects, this type of incentive may not be appropriate for managers whose decisions have significant effects on future periods. Accounting earnings are also subject to management manipulation.

The problem of emphasizing short-term performance can be reduced by using stock-based incentive schemes. Jensen and Murphy(2010, 1990) argue that executive inside stock ownership and stock options can be used to link executives' wealth to the value of the firm. As noted by Abdel-khalik (1998), when executives receive their contingent pay in a form of stock or stock options grants, they face a payoff that is related to their firm performance and to the changes in share prices. These incentive plans are assumed to encourage executives to emphasize both current and future performance. Abdel-khalik (1998) examined the effect of different stock-based incentive schemes. He posits that "CEOs who own more options than current equity shares will increase their wealth only when prices rise and, therefore, do not share in the downside risk as much as those CEOs who own more equity shares" (Abdel-khalik, 1998, p. 9). His results suggest that although risk sharing is related to stock performance, different types of equity instruments induce different incentives. His study, like other limited research examining risk-sharing effect on corporate performance, may be criticized on the ground that it employs measures that are not refined enough to explain the relationship between executive compensation and corporate performance. Most of that research, however, investigates the relationship between CEO compensation and corporate performance, ignoring the effect of risk sharing embodied in the compensation contracts of other top executives. More research is needed to provide more evidence as to the relationship between CEO and other executives risk sharing and stock performance, and to examine whether different incentive instruments have different effects on current and future stock performance. This study addresses these issues by examining two propositions: The first is that there is a positive relationship between the level of risk sharing in executive compensation contracts and stock performance of the firms they manage. The second proposition is that, contrary to a cash bonus, stock-based incentives enhance future, rather than current, stock performance. Formally stated, the first two hypotheses of this study are: 
H1: Stock of firms managed by relatively high risk sharing executives performs better than those of firms managed by relatively low risk sharing executives.

H2: Future stock performance of firms with more intensive stock-based incentives will be better than those of firms with less intensive stock-based contracts.

\subsection{Risk Sharing in New Economy Firms}

The term "new economy firms" is new in the literature. As defined by Murphy (2003), new economy firms are "companies competing in computer, software, internet, telecommunications, or networking fields." (p. 131). Recent literature provide strong evidence that new economy firms rely more on stock-based compensation than do old economy firms (Ittner et al, 2003; Murphy, 2003; Anderson et al., 2000). Hall and Liebman (1998) have noted that stock options have become a common component of executive compensation contract in publicly traded corporations. The importance of options and other forms of stock-based compensation is more evident in the new economy firms (Murphy, 2003). This might be due to the distinct characteristics of those firms. As noted by Ittner et al. (2003), new economy firms are relatively smaller (in terms of sales and employees but not in market value) than old economy firms. They are growing more rapidly and investing more in R\&D activities. Another distinguishing characteristic of new economy firms is "the extensive use of stock options as compensation for top level executives. Stock options were embraced as a critical component contributing to the success of these companies." (Murphy, 2003, p. 146). This is consistent with the conclusions of Ittner et al. (2003) and Anderson et al. (2000). Both studies show that stock and options grants in new economy firms remain higher than grants in old economy firms after controlling for all other distinguishing variables. Combining these results with those provided by Abdel-khalik (1998), we can derive the third hypothesis as follow:

H3: Stock performance is more positively correlated to executives' risk sharing in new economy firms than in old economy firms.

The next section describes the methodology to be employed for testing the hypotheses of the study.

\section{Methodology}

\subsection{Sample and Data Sources}

The data used in this study is obtained from Compustat'sExecuComp database. Aggarwal and Samwick (1999) provide several reasons for using the ExecuComp database in executive compensation studies. First, it contains data on total compensation for the top five executives, not only the CEO, at each of the firms included in the dataset. Second, it contains data on the executives' holding of stock in their own companies and existing stock options of their own company's stock. Third, it provides data for a very wide cross-section of firms. Fourth, it provides data on the total return to shareholders in each year, specified in percent returns and the market value of the firm at the beginning of each year. An initial large sample was selected for the period 1996 to 2006. It was then screened for missing data and a final usable sample of 6,084 firm-year observations was obtained.

\subsection{Variable Definitions}

The current study is concerned with the effect of executive risk sharing on stock performance. Two dependent variables are used to represent stock performance; the market price per share (MVPS), and the total return to common shareholders (TRCS). As in Murphy (2003), the total return to shareholders is measured by the market value at the beginning of the year multiplied by the percent of return to common shareholders. MVPS was chosen for two reasons: First, prior research shows that share price is a powerful inventive device as it aggregates the information of many investors about the value of the firm, and that stock market reacts to the announcement of stock-based incentive schemes (Bhagat et al., 1985). Second, share price may provide information about executive activities which cannot be inferred by analyzing long-term value of the firm (Grant et al., 1995). TRCS was also chosen for three reasons: First, it is not subject to manipulation by management. Second, prior research shows that it is a good measure of the change in the firm's financial condition. Third, Executives' wealth is usually tied directly to stock return when stock options or other share ownership plans are used in the incentive scheme.

In order to examine the effect of risk sharing compensation on each of the dependent variables, three independent variables were identified: The first is the percentage of the number of shares currently owned by top executives to the total number of voting shares outstanding at the beginning of the year (SHOS). The second is the stock-based compensation (SBC) measured, as in Murphy (2003), by the sum of restricted stock grants (valued at the grant-date market price) and stock options (valued at the grant-date using ExecuComp's modified Black-Scholes methodology). The third independent variable is the percentage of the bonus to the total variable compensation granted in a year (CBC), where total variable compensation is measured by total compensation minus the salary. Due to the nature of the 
empirical data used in this study and to reduce the effect of extreme values, the natural logarithm of each of the variables is used in the regression analysis. The reason for choosing these independent variables is to examine the effect of different incentive instruments on the dependent variables. Additionally, as control variables, firm size and total risk were included in the models. The natural logarithm of sales was used as a proxy for firm size. As in prior research, Black-Scholes volatility measured as a standard deviation volatility calculated over 60 months was used as a proxy for total risk.

\subsection{The Models}

In order to determine if the market value per share and total return to shareholders are related to the level of risk sharing of the executives, and whether different incentive instruments have different effects on current and future stock performance, four multiple regression models were used. The first two models are to test the effect of risk sharing on the current year stock performance. They are presented as follows:

$$
\begin{aligned}
& \ln (\mathrm{MVBS})_{\mathrm{t}}=\mathrm{a}_{0}+\mathrm{a}_{1} \ln (\mathrm{SHOS})_{\mathrm{t}}+\mathrm{a}_{2} \ln (\mathrm{SBC})_{\mathrm{t}}+\mathrm{a}_{3} \ln (\mathrm{CBC})_{\mathrm{t}}+\mathrm{a}_{4} \ln (\text { Sales })_{\mathrm{t}}+\mathrm{a}_{5} \text { Risk }+\varepsilon \\
& \ln (\mathrm{TRCS})_{\mathrm{t}}=\mathrm{b}_{0}+\mathrm{b}_{1} \ln (\mathrm{SHOS})_{\mathrm{t}}+\mathrm{b}_{2} \ln (\mathrm{SBC})_{\mathrm{t}}+\mathrm{b}_{3} \ln (\mathrm{CBC})_{\mathrm{t}}+\mathrm{b}_{4} \ln (\text { Sales })_{\mathrm{t}}+\mathrm{b}_{5} \text { Risk }+\varepsilon
\end{aligned}
$$

Where,

$\ln (\mathrm{MVBS})_{\mathrm{t}}=$ the natural logarithm of the market value per share in year $\mathrm{t}$.

$\ln (\text { TRCS })_{\mathrm{t}}=$ the natural $\log$ of the total return to shareholder in year $\mathrm{t}$.

$\ln (\mathrm{SHOS})_{\mathrm{t}}=$ the natural $\log$ of the percentage of currently owned shares in year $\mathrm{t}$.

$\ln (\mathrm{SBC})_{\mathrm{t}}=$ the natural logarithm of stock-based compensation.

$\ln (\mathrm{CBC})_{\mathrm{t}}=$ the natural logarithm of non-stock-based compensation.

$\ln (\text { Sales })_{\mathrm{t}}=$ the natural logarithm of firm sales in year $\mathrm{t}$.

Risk $=$ Black-Scholes volatility.

These two models will be used to test for the relationship between each of the independent variables in year $t$, and each of the dependent variables in the same year.The other two models are used to test for the effect of risk sharing on future performance. They are as follows:

$$
\begin{aligned}
& \ln (\mathrm{MVBS})_{\mathrm{t}+1}=\mathrm{a}_{0}+\mathrm{a}_{1} \ln (\mathrm{SHOS})_{\mathrm{t}}+\mathrm{a}_{2} \ln (\mathrm{SBC})_{\mathrm{t}}+\mathrm{a}_{3} \ln (\mathrm{CBC})_{\mathrm{t}}+\mathrm{a}_{4} \ln (\text { Sales })_{\mathrm{t}}+\mathrm{a}_{5} \text { Risk }+\varepsilon \\
& \ln (\mathrm{TRCS})_{\mathrm{t}+1}=\mathrm{b}_{0}+\mathrm{b}_{1} \ln (\mathrm{SHOS})_{\mathrm{t}}+\mathrm{b}_{2} \ln (\mathrm{SBC})_{\mathrm{t}}+\mathrm{b}_{3} \ln (\mathrm{CBC})_{\mathrm{t}}+\mathrm{b}_{4} \ln (\text { Sales })_{\mathrm{t}}+\mathrm{b}_{5} \text { Risk }+\varepsilon
\end{aligned}
$$

Where,

$\ln (\mathrm{MVBS})_{\mathrm{t}+1}=$ the natural logarithm of the market value per share in year $\mathrm{t}+1$.

$\ln (\mathrm{TRCS})_{\mathrm{t}+1}=$ the natural logarithm of the total return to shareholder in year $\mathrm{t}+1$.

The other variables are as defined in the first two models. These two models will be used to test for the effect of incentives in year $t$ on future performance in year $t+1$.

\section{Results}

\subsection{Descriptive Statistics}

To test for the first two hypotheses, the final sample was partitioned based on the percentage of variable compensation to total compensation into two sub-samples: high-risk sharing firms $(\mathrm{N}=3,183)$, and low-risk sharing firms $(\mathrm{N}=2,901)$. To test for the third hypothesis, the final sample was partitioned into two sub-samples based on the primary SIC code. The first sub-sample includes the new economy firms ( $\mathrm{N}=749)$ as defined by Murphy (2003), while the other sub-sample includes the old economy firms $(\mathrm{N}=2,530)$. Table 1 presents the descriptive statistics of the samples.

Insert Table 1 about here

\subsection{Regression Results}

To test for the first two hypotheses, the four models were used for the whole sample and for each of the high-risk sharing and low-risk sharing sub-samples. Table 2 and Table 3 show the results of the regression analyses and the correlation results respectively (Note 1).The results indicate that the level of risk sharing does not influence thefuture market value of shares in high-risk sharing firms. However, it does negatively influence the future market value of shares in low-risk sharing firms, as well as the current and future return to shareholders in both types of firms. The results also indicate that more intensive stock-based contracts positively influence current and future stock performance. This indicates that although stock based compensation includes a level of risk sharing, the level of risk sharing is not 
what drives stock performance in high-risk firms. Rather, it is the value of the stock based compensation that drives performance leading to a higher market value per share and higher return to shareholders.

Insert Table 2 about here

Insert Table 3 about here

To test for the third hypothesis, the four models were used with each of the new economy firms and the old economy firms sub-samples. The results show that the level of risk sharing does not influence the future market value of shares in new economy firms. However, it does negatively influence the future market value of shares in old economy firms, as well as the current and future return to shareholders in both new economy and old economy firms. The results also indicate that more intensive stock-based contacts positively influence current and future stock performance in both types of firms. As with the case of high-risk sharing firms, these results indicate that although stock based compensation includes a level of risk sharing, the level of risk sharing is not what drives stock performance in new economy firms. Alternatively, it is the value of the stock based compensation that drives performance leading to a higher market value per share and higher return to shareholders. The results also indicate that firm size does not influence the current and future market value of shares in new economy firms. This is due to the structure of these types of firms and the nature of their compensation contracts.

\section{Conclusion}

Much of the research on the relationship between executive compensation and firm performance in publicly owned corporations employs the agency theory to explain how incentives in compensation contracts affect performance (e.g., Indjejikian, 1999; Bushman \&Indjejikian, 1993; Lambert \&Larcker, 1987). A common proposition underlying this line of research is that in order to motivate executives to work for the best interest of the shareholders, compensation contracts should include some form of incentive component (Hayes \& Schaefer, 2000; Indjejikian, 1999; Baber et al., 1999; Sloan, 1993). Despite the differences in compensation contracts used in different firms, they embody both the incentive and risk sharing components.

This study builds on the existing literature by empirically investigating the relationship between executive risk sharing and the firm's stock performance in new and old economy firms. It tries to answer the fundamental question of whether or not using risk sharing contracts actually motivate executives to increase shareholder value, and whether that effect differs between new and old economy firms. The results show that the level of risk sharing does not influence the future market value of firm shares in high-risk sharing and new economy firms. However, it does negatively influence the current and future return to shareholders. The results also indicate that more intensive stock-based contacts positively influence current and future stock performance. These results indicate that although stock based compensation contracts include a level of risk sharing, the level of risk sharing is not what drives stock performance in high-risk sharing and new economy firms. Instead, it is the value of the stock based compensation that drives performance leading to a higher market value per share and higher return to shareholders. The results also indicate that firm size does not influence the current and future market value of shares in new economy firms. This is due to the structure of these types of firms and the nature of their compensation contracts where stock-based compensation is extensively used compared to old economy firms. These results should be considered in the context of the inherent limitation of this study. The study does not include all possible variables that may influence or otherwise explain the relationship between executive compensation, the value of shares and return to shareholders.

\section{References}

Abdel-khalik, A.R. (1998). CEO Compensation Risk and Shareholders' Wealth. Unpublished manuscript.University of Florida, Gainesville, FL.

Abowd, J. (1990). Does Performance-Based Managerial Compensation Affect Corporate Performance? Industrial and Labor Relations Review. (February): 52S-73S. http://dx.doi.org/10.2307/2523571

Aggarwal, R., \&Samwick, A. A. (1999). The Other Side of Tradeoff: The Impact of Risk on Executive Compensation. Journal of Political Economy. 107(1): 55-105. 
Anderson, M., Banker, R.\&Ravindran, S. (2000). Executive Compensation in the Information Technology Industry. Management Science.46: 530-547. http://dx.doi.org/10.1287/mnsc.46.4.530.12055

Baber, W., Kang, S.,\& Kumar, K. (1999). The Explanatory Power of Earnings Levels vs. Earnings Changes in the Context of Executive Compensation. The Accounting Review. (October): 459-472. http://dx.doi.org/10.2308/accr.1999.74.4.459

Bhagat, J., Brickley, J., \&Lease, R. (1985). Incentive Effects of Stock Purchase Plans. Journal of Financial Economics. 14: 195-215. http://dx.doi.org/10.1016/0304-405X(85)90014-5

Bizjak, J.M., Brickley, J. A., \&Coles, J. L. (1993). Stock-Based Incentive Compensation and Investment Behavior. Journal of Accounting and Economics. 16: 349-372. http://dx.doi.org/10.1016/0165-4101(93)90017-A

Bushman, R., \&Indjejikian, R. (1993). Accounting Income, Stock Price, and Managerial Compensation. Journal of Accounting and Economics. 16: 3-23. http://dx.doi.org/10.1016/0165-4101(93)90003-X

Clinch, G. (1991). Employee Compensation and Firms' Research and Development Activity. Journal of Accounting Research. 29: 59-78. http://dx.doi.org/10.2307/2491028

El Akremi, A., Roussel, P.,\&Trepo, G. (2001). CEO Compensation Strategies: Consequences on the Structure and Management of Executive Pay.LIRHE CNRS unpublished manuscript.University of Toulouse, Toulouse, France.

Gaver, J., \&Gaver, K. (1993). The Association between Performance-Plan Adoption and Corporate Capital Investment: A Note. Journal of Management Accounting Research. Fall(5): 145-158.

Gomaa, M. (2003). An Empirical Investigation of the Relationship between Executive Risk Sharing and Stock Performance. Unpublished manuscript, University of South Florida, Tampa, FL.

Gong, J. (2011). Examining Shareholder Value Creation over CEO Tenure: A New Approach to Testing Effectiveness of Executive Compensation. Journal of Management Accounting Research. 23(1): 1-128. http://dx.doi.org/10.2308/jmar-10105

Grant, S., King, S., \&Polak, B. (1995). Information Externalities, Share-Price Based Incentives and Management Behavior. Cowles Foundation Discussion Paper 1107.

Hall, B.,\&Liebman, J. (1998). Are CEOs Really Paid Like Bureaucrats? Quarterly Journal of Economics. (August): 653-691.

Hayes, R. M.,\& Schaefer, S. (2000). Implicit Contracts and the Explanatory Power of Top Executive Compensation for Future Performance. Rand Journal of Economics. (Summer): 273-293.

Holmstrom, B. (1979). Moral Hazard and Observability.The Bell Journal of Economics, 10: 47-91. http://dx.doi.org/10.2307/3003320

Indjejikian, R. (1999). Performance Evaluation and Compensation Research: An Agency Perspective. Accounting Horizon. (June): 147-157. http://dx.doi.org/10.2308/acch.1999.13.2.147

Ittner, C, Lambert, R.,\& Larker, D. (2003). The Structure and Performance Consequences of Equity Grants to Employees of New Economy Firms. Journal of Accounting and Economics. (January): 89-127.

Jensen, M. C.,\& Murphy, K. J. (2010). CEO incentives - It's not how much you pay, but how. Journal of Applied Corporate Finance. 22: 64-76. http://dx.doi.org/10.1111/j.1745-6622.2010.00262.x

Jensen, M. C.,\&Murphy, K. J. (1990). Performance Pay and Top Management Incentives. Journal of Political Economy. 98: 225-264.

Kren, L. (2001). The Relation Between Chief Executive Compensation and Financial Performance: The Information Effect of Diversification. Advances in Management Accounting Research. 10: 141-169.

Lambert, R., \&Larcker, D. F. (1987). An Analysis of the Use of Accounting and Market Measures of Performance in Executive Compensation Contracts. Journal of Accounting Research. 25: 85-125. http://dx.doi.org/10.2307/2491081

Leonard, J. (1990). Executive Pay and Firm Performance.Industrial and Labor Relations Review. (February): 13S-29S. http://dx.doi.org/10.2307/2523569

Murphy, K. (2003). Stock-Based Pay in New Economy Firms. Journal of Accounting and Economics.(January): 129-147. http://dx.doi.org/10.1016/S0165-4101(02)00090-3

Shim, E., Lee, J.,\&Carrigan, T. (1999). An Empirical Examination of Top Executive Compensation and Economic Performance in Financial Service Firms. Advances in Management Accounting. 8: 225-237. 
Sigler, K. J. (2011). CEO Compensation and Company Performance. Business and Economics Journal. 31: 1-7.

Sloan, R.G. (1993). Accounting Earnings and Top Executive Compensation. Journal of Accounting and Economics. (January): 55-100.http://dx.doi.org/10.1016/0165-4101(93)90005-Z

Vieito,J. P., Cerqueira, A., Brandão, E.,\& Khan, W. (2008). Executive Compensation: New vs. Old Economy and the Impact of NasdaqCrash and Sarbanes Oxley Act. Proceedings of the Financial Management Association European Conference, Prague, Czech Republic.

Yermack, D. (1995). Do Corporation Award CEO Stock Options Effectively. Journal of Financial Economics. 39: 237-269. http://dx.doi.org/10.1016/0304-405X(95)00829-4

Note 1.Additional tests of multicollinearity showed a VIF between 1 and 1.15, with a tolerance value between 0.82 and 0.99 , indicating no multicollinearity problem with the data.

Table 1. Descriptive Statistics - Mean (Standard Deviation) of Variables

\begin{tabular}{lccccc}
\hline \hline & Old Economy & New Economy & High Risk & Low Risk & Total Sample \\
& Firms $^{1}$ & Firms $^{1}$ & Firms $^{2}$ & Firms & \\
& $\mathrm{N}=2,530$ & $\mathrm{~N}=749$ & $\mathrm{~N}=3,183$ & $\mathrm{~N}=2,901$ & $\mathrm{~N}=6,084$ \\
\hline \multirow{2}{*}{$\ln$ (MVBS) } & 3.0808 & 2.9806 & 3.2925 & 2.8892 & 3.1002 \\
& $(0.7210)$ & $(0.8068)$ & $(0.6684)$ & $(0.7358)$ & $(0.7296)$ \\
\hline \multirow{2}{*}{$\ln$ (TRCS) } & 9.2127 & 9.451 & 10.0015 & 8.8386 & 9.4470 \\
& $(1.5855)$ & $(1.8235)$ & $(1.6343)$ & $(1.4424)$ & $(1.6512)$ \\
\hline \multirow{2}{*}{$\ln$ (SHOS) } & 1.3772 & 1.3893 & 1.3481 & 1.4086 & 1.3770 \\
& $(1.0672)$ & $(0.9736)$ & $(1.0182)$ & $(1.0432)$ & $(1.0305)$ \\
\hline \multirow{2}{*}{$\ln$ (SBC) } & 7.9422 & 8.6470 & 8.9120 & 6.9991 & 7.9999 \\
& $(1.4770)$ & $(1.5412)$ & $(1.4440)$ & $(1.0407)$ & $(1.5875)$ \\
\hline \multirow{2}{*}{$\ln (\mathrm{CBC})$} & 3.1948 & 2.5899 & 2.7625 & 3.3912 & 3.0623 \\
& $(0.8291)$ & $(1.0411)$ & $(0.9696)$ & $(0.7331)$ & $(0.9201)$ \\
\hline \multirow{2}{*}{$\ln$ (Sales) } & 6.6345 & 5.7803 & 6.7309 & 6.6682 & 6.6991 \\
& $(1.8318)$ & $(1.8969)$ & $(1.8416)$ & $(1.7879)$ & $(1.8148)$ \\
\hline \multirow{2}{*}{ Risk } & 0.4377 & 0.6668 & 0.4630 & 0.4553 & 0.4591 \\
& $(0.2982)$ & $(0.3060)$ & $(0.3311)$ & $(0.3316)$ & $(0.3313)$ \\
\hline \hline
\end{tabular}

${ }^{1}$ As defined by Murphy (2003), new economy firms are companies with primary SIC codes 3570, 3571, 3572, 3576, 3577, 3661, 3674, 4812, 4813, $5045,5961,7370,7371,7372$, and 7373 . Old economy firms are firms with primary SIC codes less than 4000 that have not been categorized as new economy firms.

${ }^{2}$ Based on the percentage of variable compensation to total compensation. 
Table 2. Regression Results $-\mathrm{t}$-value (significance)

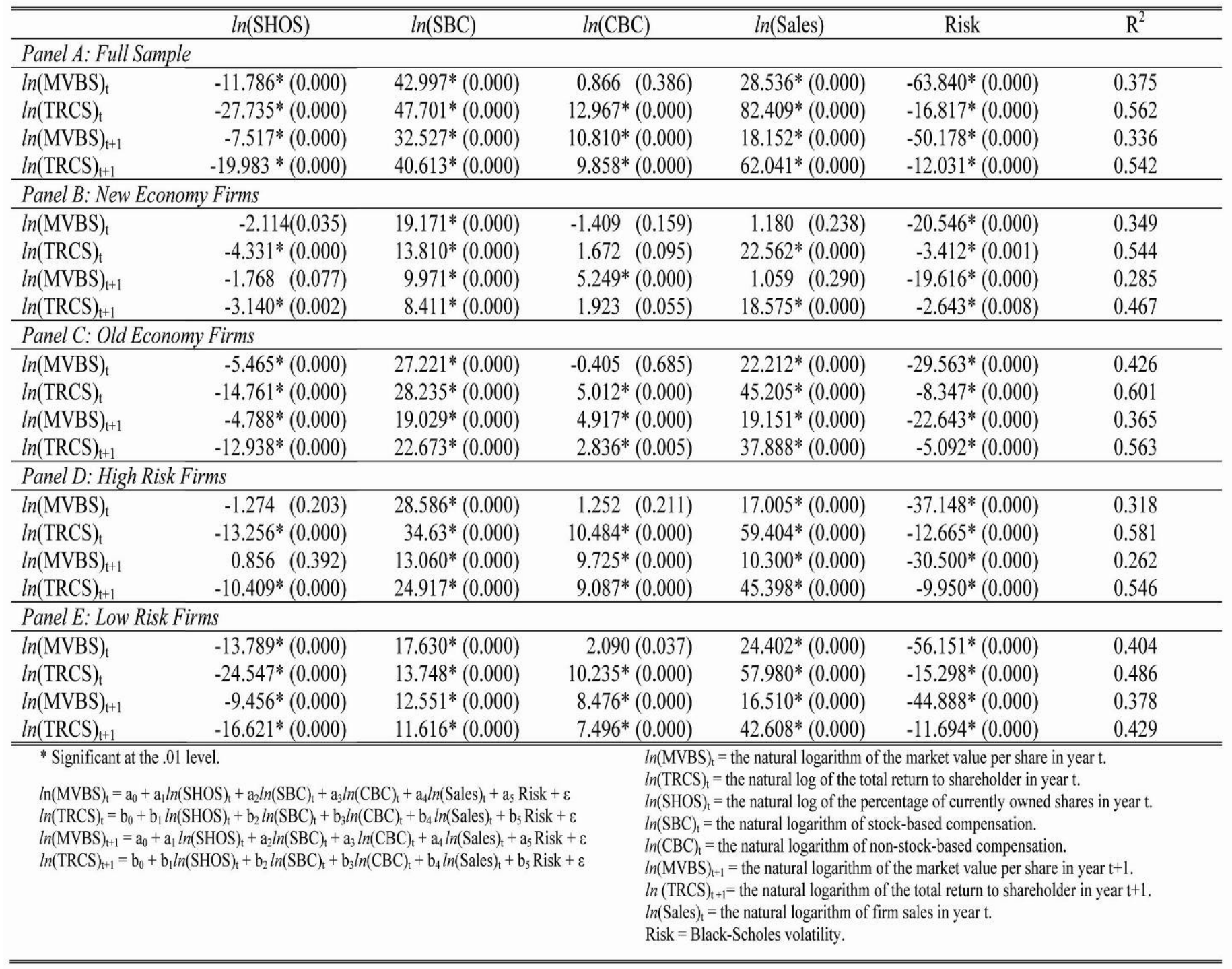


Table 3. Correlation Results - Correlation Coefficient (significance)

\begin{tabular}{|c|c|c|c|c|c|}
\hline & $\ln (\mathrm{SHOS})_{\mathrm{t}}$ & $\ln (\mathrm{SBC})_{\mathrm{t}}$ & $\ln (\mathrm{CBC})_{\mathrm{t}}$ & $\ln (\text { Sales })_{\mathrm{t}}$ & Risk \\
\hline \multicolumn{6}{|c|}{ Panel A: Full Sample } \\
\hline $\ln (\mathrm{MVBS})_{\mathrm{t}}$ & $-0.041 * *(0.000)$ & $0.374 * *(0.000)$ & $0.018 * *(0.003)$ & $0.471 * *(0.000)$ & $-0.463 * *(0.000)$ \\
\hline $\ln (\mathrm{TRCS})_{\mathrm{t}}$ & $-0.068^{* *}(0.000)$ & $0.045^{* *}(0.000)$ & $0.020 * *(0.004)$ & $0.703 * *(0.000)$ & $-0.290 * *(0.000)$ \\
\hline $\ln (\mathrm{MVBS})_{\mathrm{t}+1}$ & $-0.032 *(0.014)$ & $0.316^{* *}(0.000)$ & $0.097 * *(0.000)$ & $0.432 * *(0.000)$ & $-0.461 * *(0.000)$ \\
\hline $\ln (\mathrm{TRCS})_{\mathrm{t}+1}$ & $-0.062 * *(0.000)$ & $0.489 * *(0.058)$ & $-0.017 *(0.058)$ & $0.678 * *(0.000)$ & $-0.279 * *(0.000)$ \\
\hline $\ln (\mathrm{SHOS})_{\mathrm{t}}$ & & $0.002 \quad(0.866)$ & $-0.004 \quad(0.712)$ & $-0.218 * *(0.000)$ & $0.043 * *(0.000)$ \\
\hline $\ln (\mathrm{SBC})_{\mathrm{t}}$ & & & $-0.381 * *(0.000)$ & $0.377 * *(0.000)$ & $-0.044 * *(0.000)$ \\
\hline $\ln (\mathrm{CBC})_{\mathrm{t}}$ & & & & $0.145 *(0.000)$ & $-0.264 * *(0.000)$ \\
\hline $\ln (\text { Sales })_{\mathrm{t}}$ & & & & & $-0.338 * *(0.000)$ \\
\hline \multicolumn{6}{|c|}{ Panel B: New Economy Firms } \\
\hline $\ln (\mathrm{MVBS})_{\mathrm{t}}$ & $-0.052(0.078)$ & $0.460 * *(0.000)$ & $-0.118^{* *}(0.000)$ & $0.380 * *(0.000)$ & $-0.376 * *(0.000)$ \\
\hline $\ln (\mathrm{TRCS})_{\mathrm{t}}$ & $-0.017(0.633)$ & $0.541 * *(0.000)$ & $-0.066 *(0.004)$ & $0.698 *(0.000)$ & $-0.240 * *(0.000)$ \\
\hline $\ln (\mathrm{MVBS})_{t+1}$ & $-0.042(0.193)$ & $0.220 * *(0.000)$ & $0.115^{* *}(0.000)$ & $0.292 * *(0.000)$ & $-0.454 * *(0.000)$ \\
\hline $\ln (\mathrm{TRCS})_{\mathrm{t}+1}$ & $0.009(0.813)$ & $0.468 * *(0.000)$ & $-0.043 \quad(0.098)$ & $0.652 * *(0.000)$ & $-0.235 * *(0.000)$ \\
\hline $\ln (\mathrm{SHOS})_{\mathrm{t}}$ & & $0.048 \quad(0.103)$ & $-0.120 * *(0.000)$ & $-0.218 * *(0.000)$ & $0.017 \quad(0.396)$ \\
\hline $\ln (\mathrm{SBC})_{\mathrm{t}}$ & & & $-0.415 * *(0.000)$ & $0.442 * *(0.000)$ & $0.033 \quad(0.080)$ \\
\hline $\ln (\mathrm{CBC})_{\mathrm{t}}$ & & & & $0.054 * *(0.000)$ & $-0.263 * *(0.000)$ \\
\hline $\ln (\text { Sales })_{\mathrm{t}}$ & & & & & $-0.369 * *(0.000)$ \\
\hline \multicolumn{6}{|c|}{ Panel C: Old Economy Firms } \\
\hline $\ln (\mathrm{MVBS})_{\mathrm{t}}$ & $-0.054 * *(0.000)$ & $0.465^{* *}(0.000)$ & $\begin{array}{ll}-0.009 & (0.433)\end{array}$ & $0.549 *(0.000)$ & $-0.445^{* *}(0.000)$ \\
\hline $\ln (\mathrm{TRCS})_{\mathrm{t}}$ & $-0.099 * *(0.000)$ & $0.559 * *(0.000)$ & $-0.046^{* *}(0.000)$ & $0.731 *(0.000)$ & $-0.303 * *(0.000)$ \\
\hline $\ln (\mathrm{MVBS})_{\mathrm{t}+1}$ & $-0.035 \quad(0.064)$ & $0.384 * *(0.000)$ & $0.070 * *(0.000)$ & $0.520 *(0.000)$ & $-0.427 * *(0.000)$ \\
\hline $\ln (\mathrm{TRCS})_{\mathrm{t}+1}$ & $-0.100 * *(0.000)$ & $0.542 * *(0.000)$ & $-0.051 * *(0.000)$ & $0.709 * *(0.000)$ & $-0.282 * *(0.000)$ \\
\hline $\ln (\mathrm{SHOS})_{\mathrm{t}}$ & & $-0.070 * *(0.000)$ & $0.058 * *(0.002)$ & $-0.250 * *(0.000)$ & $0.062 * *(0.000)$ \\
\hline $\ln (\mathrm{SBC})_{\mathrm{t}}$ & & & $-0.354 * *(0.000)$ & $0.469 * *(0.000)$ & $-0.099 * *(0.000)$ \\
\hline $\ln (\mathrm{CBC})_{\mathrm{t}}$ & & & & $0.146 * *(0.000)$ & $-0.223 * *(0.000)$ \\
\hline $\ln (\text { Sales })_{\mathrm{t}}$ & & & & & $-0.396^{* *}(0.000)$ \\
\hline \multicolumn{6}{|c|}{ Panel D: High Risk Firms } \\
\hline $\ln (\mathrm{MVBS})_{\mathrm{t}}$ & $-0.034 *(0.026)$ & $0.384 * *(0.000)$ & $0.064 * *(0.000)$ & $0.447 * *(0.000)$ & $-0.420 * *(0.000)$ \\
\hline $\ln (\mathrm{TRCS})_{\mathrm{t}}$ & $-0.067 * *(0.000)$ & $0.474 * *(0.000)$ & $0.125^{* *}(0.000)$ & $0.722 * *(0.000)$ & $-0.322 * *(0.000)$ \\
\hline $\ln (\mathrm{MVBS})_{\mathrm{t}+1}$ & $-0.018 \quad(0.325)$ & $0.218 * *(0.000)$ & $0.199 * *(0.000)$ & $0.405 * *(0.000)$ & $-0.430 * *(0.000)$ \\
\hline $\ln (\text { TRCS })_{t+1}$ & $-0.054 * *(0.009)$ & $0.446 * *(0.000)$ & $0.126 * *(0.000)$ & $0.701 * *(0.000)$ & $-0.316^{* *}(0.000)$ \\
\hline $\ln (\mathrm{SHOS})_{\mathrm{t}}$ & & $0.050 * *(0.001)$ & $-0.006 \quad(0.724)$ & $-0.194 * *(0.000)$ & $0.063 * *(0.000)$ \\
\hline $\ln (\mathrm{SBC})_{\mathrm{t}}$ & & & $-0.278 * *(0.000)$ & $0.985 * *(0.000)$ & $-0.040 * *(0.000)$ \\
\hline $\ln (\mathrm{CBC})_{\mathrm{t}}$ & & & & $0.246 * *(0.000)$ & $-0.282 * *(0.000)$ \\
\hline $\ln (\text { Sales })_{\mathrm{t}}$ & & & & & $-0.348 * *(0.000)$ \\
\hline \multicolumn{6}{|c|}{ Panel E: Low Risk Firms } \\
\hline $\ln (\mathrm{MVBS})_{\mathrm{t}}$ & $-0.043 * *(0.006)$ & $0.287 * *(0.000)$ & $0.115^{* *}(0.000)$ & $0.469 * *(0.000)$ & $-0.550 * *(0.000)$ \\
\hline $\ln (\mathrm{TRCS})_{\mathrm{t}}$ & $-0.067 * *(0.000)$ & $0.269 * *(0.000)$ & $0.124 * *(0.000)$ & $0.658 * *(0.000)$ & $-0.328 * *(0.000)$ \\
\hline $\ln (\mathrm{MVBS})_{\mathrm{t}+1}$ & $-0.041 *(0.024)$ & $0.242 * *(0.000)$ & $0.189 * *(0.000)$ & $0.433 * *(0.000)$ & $-0.529 * *(0.000)$ \\
\hline $\ln (\mathrm{TRCS})_{\mathrm{t}+1}$ & $-0.071 * *(0.000)$ & $0.289 * *(0.000)$ & $0.116^{* *}(0.000)$ & $0.629 * *(0.000)$ & $-0.308 * *(0.000)$ \\
\hline $\ln (\mathrm{SHOS})_{\mathrm{t}}$ & & $-0.037 *(0.021)$ & $-0.002 \quad(0.917)$ & $-0.272 * *(0.000)$ & $0.015 \quad(0.070)$ \\
\hline $\ln (\mathrm{SBC})_{\mathrm{t}}$ & & & $-0.205^{* *}(0.000)$ & $0.329 * *(0.000)$ & $-0.181 * *(0.000)$ \\
\hline $\ln (\mathrm{CBC})_{\mathrm{t}}$ & & & & $0.172 * *(0.000)$ & $-0.221 * *(0.000)$ \\
\hline $\ln (\text { Sales })_{\mathrm{t}}$ & & & & & $-0.329 * *(0.000)$ \\
\hline
\end{tabular}

** Significant at the .01 level.

* Significant at the .05 level.

$\ln (\text { MVBS })_{\mathrm{t}}=$ the natural logarithm of the market value per share in year $\mathrm{t}$.

$\ln (\mathrm{TRCS})_{\mathrm{t}}=$ the natural $\log$ of the total return to shareholder in year $\mathrm{t}$.

$\ln (\mathrm{SHOS})_{\mathrm{t}}=$ the natural $\log$ of the percentage of currently owned shares in year $\mathrm{t}$.

$\ln (\mathrm{SBC})_{\mathrm{t}}=$ the natural logarithm of stock-based compensation.

$\ln (\mathrm{CBC})_{\mathrm{t}}=$ the natural logarithm of non-stock-based compensation.

$\ln (\mathrm{MVBS})_{t+1}=$ the natural logarithm of the market value per share in year $\mathrm{t}+1$.

$\ln (\text { TRCS })_{t+1}=$ the natural logarithm of the total return to shareholder in year $\mathrm{t}+1$.

$\ln (\text { Sales })_{\mathrm{t}}=$ the natural logarithm of firm sales in year $\mathrm{t}$.

Risk $=$ Black-Scholes volatility . 